\title{
Rivaroxaban: např́ič spektrem indikací a profilů pacientů
}

Na sjezdu České kardiologické společnosti v Brně v květnu 2015 proběhla hned tři symposia věnovaná perorálnímu antikoagulanciu rivaroxabanu. Zabývala se prínosem tohoto přímého inhibitoru faktoru Xa v prevenci cévních mozkových príhod (CMP) a systémové embolie (SE) u pacientů s nevalvulární fibrilací síní (NVFS), včetně rizikových pacientů se sníženou renální funkcí a diabetem, účinnosti a bezpečnosti rivaroxabanu u pacientů s plánovanou kardioverzí pro nevalvulární FS prokázané ve studii X-VeRT a praktickým zkušenostem s rivaroxabanem v léčbě tromboembolické nemoci (TEN).

\section{Program klinických studií a registrů s rivaroxabenem zahrnuje přes 275000 pacientů}

Prof. MUDr. Miloš Táborský, Ph.D., MBA, FESC (I. interní klinika, LF UP a FN Olomouc) provedl účastníky symposia vývojem rivaroxabanu až po jeho využití v reálné klinické praxi. V roce 1998 bylo z databáze zhruba 200 000 molekul identifikováno pět látek schopných inhibovat faktor Xa a bylo zahájeno jejich testování. V roce 1999 byla vybrána molekula s vysokou absorpcí, ale nízkou aktivitou. Úpravou molekuly zvyšující její účinnost vznikl rivaroxaban, který v roce 2000 vstoupil do preklinického testování. Studie I. fáze ukázaly dobrý farmakokinetický a farmakodynamický profil rivaroxabanu a jeho dobrou snášenlivost u zdravých dobrovolníků. Studie II. fáze ukázaly dobrý poměr prínosů a rizik, dávkovací schéma a v roce 2009 studie ATLAS s 3491 pacienty dávkování v sekundární prevenci akutního koronárního syndromu.

$\checkmark$ roce 2008 prrinesla klinická studie III. fáze RECORD 1-3 výsledky v ortopedických indikacích. Rivaroxaban v porovnání s enoxaparinem významně snížil výskyt tromboembolických príhod po operaci. $V$ roce 2009 prokázaly studie EINSTEIN DVT a EINSTEIN EXT účinnost a bezpečnost rivaroxabanu v léčbě hluboké žilní trombózy a v sekundární prevenci tromboembolických príhod. Studie ATLAS ACS TIMI 51 publikovaná v lednu 2011 ukázala účinnost rivaroxabanu v sekundární prevenci ischemických př́hod u pacientů $s$ akutním koronárním syndromem léčených kyselinou acetylsalicylovou (ASA) \pm thienopyridiny. $V$ dubnu 2012 přinesla studie EINSTEIN PE důkazy o srovnatelné účinnosti a lepší bezpečnosti rivaroxabanu v léčbě plicní embolie při srovnání se standardní terapií. Sdružená analýza dat ze studií EINSTEIN DVT a EINSTEIN PE pak potvrdila o 46 \% nižší relativní riziko závažného krvácení při léčbě rivaroxabanem v porovnání s warfarinem při srovnatelném riziku recidivy tromboembolické nemoci (TEN).

První ze studií po uvedení přípravku na trh (IV. fáze) byla studie XAMOS publikovaná v lednu 2014. U více než 17000 pacientů prokázala lepší účinnost a srovnatelnou bezpečnost rivaroxabanu v tromboprofylaxi u velkých ortopedických operací ve srovnání se standardní péči v reálné klinické praxi. V záŕí 2014 byly zveřejněny výsledky studie III. fáze X-VeRT, která hodnotila léčbu pacientů s nevalvulární fibrilací síní (NVFS) s plánovanou kardioverzí. Naznačila trend k lepší účinnosti i bezpečnosti rivaroxabanu v porovnání s warfarinem. A konečně na začátku letošního roku přinesla farmakovigilanční studie zahrnující přes 24467 pacientů léčených rivaroxabenam data z reálné klinické praxe u NVFS.
Ukázala výskyt závažných krvácení srovnatelný s výsledky studie ROCKET AF a nízký výskyt fatálních krvácení.

$V$ současné době se také objevují výsledky řady subanalýz studií III. fáze. Ukazují např., že rivaroxaban nevede ke zvýšení kardiovaskulární mortality a morbidity ani u pacientů po infarktu myokardu (IM) a s nestabilní anginou pectoris. Přinášejí náhled na přidanou terapii u polymorbidního komplexně léčeného pacienta. Také potvrdily, že perzistentní FS je spojena s vyšší mortalitou než paroxysmální FS.

Program klinických studií a postmarketingových registrů zahrnuje přes 275000 pacientů. $V$ dokončených klinických studiích III. fáze bylo rivaroxabanem ve všech indikacích dosud léčeno 53153 pacientů.

\section{Účinnost a bezpečnost rivaroxabanu byla prokázána i u pacientů s renální insuficiencí a diabetem}

Prof. MUDr. Aleš Linhart, DrSc., FESC, FCMA (II. interní klinika, 1. LF UK a VFN Praha) príibližil praktické uplatnění výsledků studie ROCKET AF s rivaroxabanem na prípadu 75leté pacientky s NVFS, diabetem 2. typu (DM2) a aktuálním vzestupem koncentrace kreatininu v séru. Připomněl, že po 66. roce věku klesá glomerulární filtrace (GF) i u osob bez diabetu, nicméně př́činou zvýšení koncentrace kreatininu v séru může být i warfarinem navozená nefropatie (WNN). Z tohoto pohledu je významné sledování INR, nebot' $k$ této nefropatii dochází do týdne po zvýšení INR nad 3,0. S prodlužující se dobou, kdy je INR > 3,0, klesá přežití pacientů léčených warfarinem. Rizikovými faktory WNN je vyšší věk, chronická renální insuficience (eGF < $60 \mathrm{ml} / \mathrm{min} / 1,73 \mathrm{~m}^{2}$ ), DM2, hypertenze, srdeční selhání a užívání ASA a heparinu.

Subanalýza pacientů s renální insuficiencí ze studie ROCKET AF ukázala, že pokles renálních funkcí je prediktorem rizika cévní mozkové príhody (CMP) a systémové embolie (SE) u pacientů s FS. Stratifikace rizika pacientů S FS je vodítkem pro zahájení antikoagulační léčby. $\mathrm{R}_{2} \mathrm{CHADS}_{2}$ skóre proto ke skóre $\mathrm{CHADS}_{2}$ přidává i dva body při eGF $<60 \mathrm{ml} / \mathrm{min} / 1,73 \mathrm{~m}^{2}$. Při indikaci antikoagulační terapie je proto třeba standardně zohlednit clearance kreatininu $(\mathrm{CrCl})$. U pacientů $\mathrm{s} \mathrm{CrCl}>50 \mathrm{ml} / \mathrm{min}$ se podává dávka $20 \mathrm{mg}$, při $\mathrm{CrCl} 15-50 \mathrm{ml} / \mathrm{min}$ dávka $15 \mathrm{mg}$ a při $\mathrm{CrCl}$ $<15 \mathrm{ml} / \mathrm{min}$ je rivaroxaban kontraindikován. Rivaroxaban je ze dvou třetin metabolizován v játrech a $z$ jedné třetiny je vylučován ledvinami. Studie ROCKET AF prokázala účinnost rivaroxabanu v dávce $15 \mathrm{mg}$ v prevenci CMP a SE u pacientů s $\mathrm{CrCl} 30-49 \mathrm{ml} / \mathrm{min}$ v porovnání s warfarinem 
(obr. 1). Účinnost i bezpečnost tohoto postupu byla srovnatelná s dávkou $20 \mathrm{mg}$ u pacientů $\mathrm{s} \mathrm{CrCl}>50 \mathrm{ml} / \mathrm{min}$. Pro pacienty s renální insuficiencí je tedy léčba sníženou dávkou rivaroxabanu stejným přínosem jako léčba plnou dávkou u pacientů s normální funkcí ledvin.

Studie ROCKET AF přináší také odpověd' na otázku léčby FS u diabetiků. Zahrnovala 5635 (39,9 \%) pacientů s DM2. Výsledky ukázaly, že rivaroxaban snižuje riziko CMP a SE více než warfarin, i když rozdíl byl hraniční bez statistické významnosti ( $\mathrm{HR}=0,74,95 \% \mathrm{Cl} 0,54-1,01$, $p=0,055)$. Výsledky porovnávající podskupinu diabetiků s ostatními pacienty neprokázaly žádný významný rozdíl $v$ účinnosti a bezpečnosti léčby rivaroxabanem. Ve studii ROCKET vykázal rivaroxaban minimálně srovnatelnou účinnost a bezpečnost u pacientů se srdečním selháním, po IM, nad 75 let věku, s hypertenzí, v sekundární prevenci CMP i u pacientů bez předchozí léčby warfarinem.

\section{Farmakologické vlastnosti rivaroxabanu přinášejí řadu výhod pro pacienty}

Doc. MUDr. Karel Urbánek, Ph.D. (Ústav farmakologie, LF UP a FN Olomouc) se věnoval farmakologickým vlastnostem rivaroxabanu. Jak připomněl, přímé inhibitory faktoru Xa mají vysokou selektivitu k tomuto koagulačnímu faktoru. $V$ porovnání s prímými inhibitory trombinu (dabigatranem) a warfarinem vykazují ve studii na zvíratech při stejné redukci trombu kratší dobu krvácení v závislosti na dávce. Přístup zaměřený na inhibici trombinu je spojen s úzkým terapeutickým indexem, naopak inhibice faktoru Xa se jeví jako optimální terapeutický cíl a prokázala zatím nejvyšší dosažitelný poměr mezi účinností a bezpečností.

Rivaroxaban je dostupný v potahovaných tabletách malého rozměru, které umožňují snadné spolknutí. Absorpce je stabilní i po rozdrcení tablety či podání nasogastrickou sondou. Pro pacienta to znamená snadné a pohodlné užívání a minimální riziko nesprávného užití. Rivaroxaban dosahuje maximální plazmatické koncentrace za 2-4 hodiny po podání. Ve vyšších dávkách je absorpce lepší s jídlem, typ stravy ji ovšem neovlivňuje. Pro pacienta z toho vyplývá minimální riziko náhlé změny vstřebávání a žádná dietní omezení. Rivaroxaban je metabolizován cytochromy CYP3A4, CYP2J a necytochromovým metabolismem a metabolity jsou ze 70 $\%$ neaktivní. $V$ klinické praxi to znamená alternativní cesty eliminace při poruše exkrece. Poločas eliminace rivaroxabanu je 5-13 hodin. Třetina podané dávky se vyloučí ledvinami v podobě účinné látky, třetina v podobě neaktivních metabolitů a třetina střevem. To je důvodem nízkého rizika předávkování nebo poddávkování při změně renálních funkcí.

Rivaroxaban je látka s výjimečně stabilní farmakokinetikou. Fyziologické variability prakticky nemají vliv na změny plazmatické koncentrace, dávkování, účinnost ani bezpečnost. $Z$ patologických variabilit je z tohoto pohledu významné jen závažné snížení funkce jater nebo ledvin. Lékové interakce jsou ve srovnání s warfarinem minimální. Nehrozí při podávání s běžnou medikací (beta-blokátory, inhibitory enzymu konvertujícího angiotensin, blokátory kalciových kanálů, amiodaron, perorální antidiabetika, inhibitory protonové pumpy, statiny, digoxin).

Dávkování rivaroxabanu u NVFS je 20 mg s odstupem přibližně 24 hodin. $U \mathrm{CrCl} 15-49 \mathrm{ml} / \mathrm{min}$ se dávka snižu-

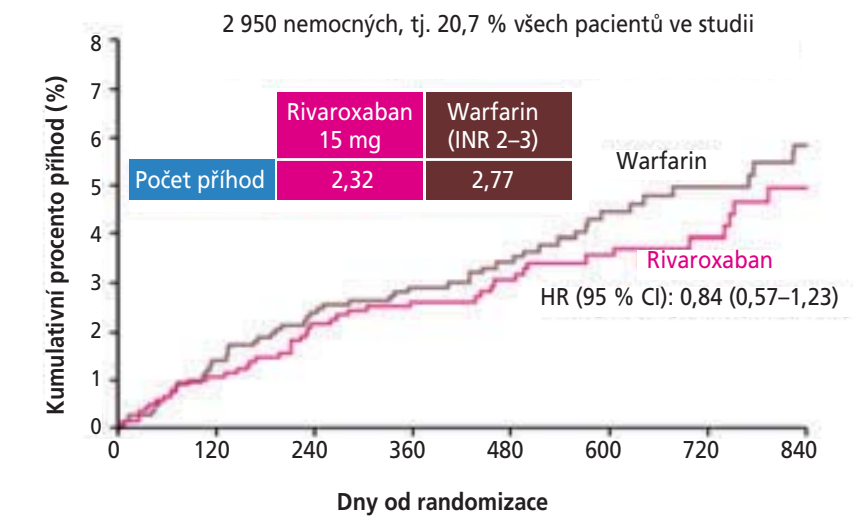

Počet pacientů s rizikem

$\begin{array}{llllllll}\text { Rivaroxaban } 1434 & 1226 & 1103 & 1027 & 806 & 621 & 442 & 275\end{array}$ $\begin{array}{lllllllll}\text { Warfarin } & 1439 & 1261 & 1140 & 1052 & 832 & 656 & 455 & 272\end{array}$

K.A. Fox, et al., European Heart Journal 32 (2011) 2387-2394.

Obr. 1 - Účinnost rivaroxabanu v dávce $15 \mathrm{mg}$ v prevenci CMP a SE u pacientů s $\mathrm{CrCl}$ 30-49 $\mathrm{ml} / \mathrm{min}$ ve studii ROCKET AF

je na $15 \mathrm{mg}$ denně. Rivaroxaban se nepodává při $\mathrm{CrC}$ $<15 \mathrm{ml} / \mathrm{min}$ a u pacientů s hepatopatií s koagulopatií. Plocha pod křivkou plazmatické koncentrace rivaroxabanu dosahuje srovnatelných hodnot při plné dávce u $\mathrm{CrCl}$ $>50 \mathrm{ml} / \mathrm{min}$ i při snížené dávce u pacientů s $\mathrm{CrCl} 30-49 \mathrm{ml} /$ min. Dávkování jednou denně významně zvyšuje compliance $s$ léčbou v porovnání s dávkováním dvakrát denně. Prokázala to pětiletá studie s 10697 pacienty s NVFS se zahájením antidiabetické nebo antihypertenzní léčby. Potvrzuje to i praxe dávkování léků v kardiologii, kde se $68 \%$ vystavených preskripcí týkalo látek podávaných jednou denně. Navíc výsledky registru DRESDEN ukázaly, že v reálné praxi užívá po devíti měsících od zahájení léčby rivaroxaban 90,7 \% pacientů v porovnání se 73,6 \% pacientů s dabigatranem.

\section{Rivaroxaban prokázal účinnost a bezpečnost u pacientů s nevalvulární fibrilací síní podstupujících kardioverzi}

V rámci druhého symposia představil MUDr. Robert Čihák, CSc. (Klinika kardiologie, IKEM, Praha) výsledky studie X-VeRT, která hodnotila účinnost a bezpečnost rivaroxabanu v prevenci kardiovaskulárních príhod u pacientů s NVAF podstupujících plánovanou kardioverzi v porovnání s titrovanou dávkou antagonistů vitaminu $\mathrm{K}$ (VKA). $\checkmark$ této multicentrické prospektivní randomizované studii zahrnující 1504 pacientů byly rivaroxaban (20 mg jednou denně) nebo VKA podávány bud' 1-5 dní (časná kardioverze), nebo 21-56 dní před kardioverzí (odložená kardioverze) a poté dalších 42 dní. Složený sledovaný parametr zahrnoval CMP, transitorní ischemickou ataku (TIA), SE, IM a úmrtí z kardiovaskulárních příčin. Výsledky ukázaly trend k lepší účinnosti rivaroxabanu (výskyt primárního sledovaného parametru u 0,5\% pacientů s rivaroxabanem a u 1,01\% pacientů s VKA, RR $=0,50$, $95 \% \mathrm{Cl} 0,15-1,73, \mathrm{NS}$ ) i bezpečnosti rivaroxabanu (výskyt krvácení u 0,6 \% vs. 0,81 \% pacientů, RR $=0,76,95 \% \mathrm{Cl}$ $0,21-2,67$ ) (obr. 2). U časné kardioverze byl čas do jejího provedení u obou terapeutických postupů srovnatelný, 
Trend k lepší účinnosti rivaroxabanu ve srovnání s warfarinem

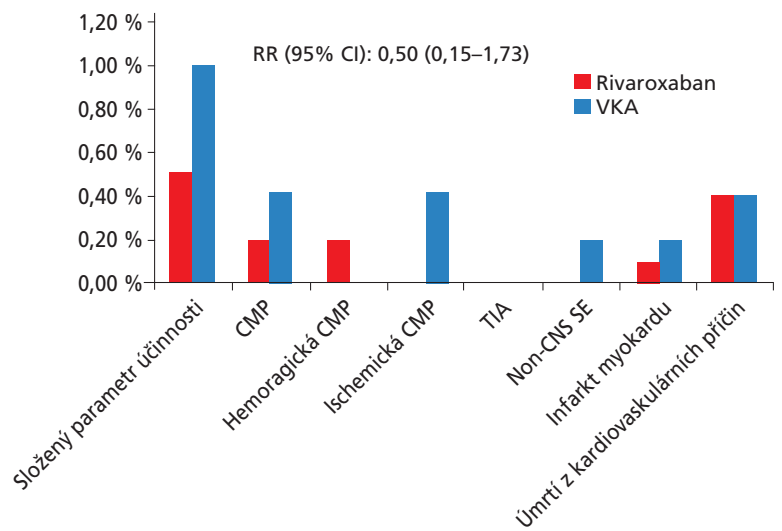

Trend k lepší bezpečnosti rivaroxabanu ve srovnání s warfarinem

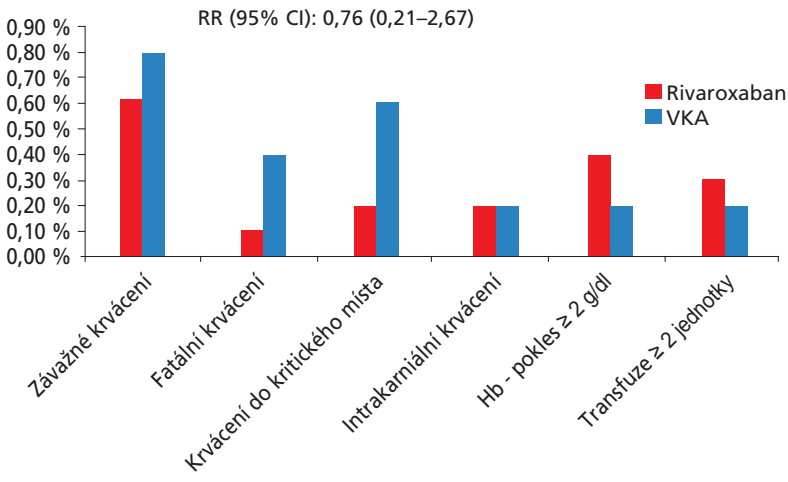

Obr. 2 - Trend k lepší účinnosti a bezpečnosti rivaroxabanu v prevenci kardiovaskulárních příhod u pacientů s NVFS podstupujících plánovanou kardioverzi v porovnání s titrovanou dávkou VKA: ve studii X-VeRT.

CMP - cévní mozková příhoda; CNS - centrální nervový systém; SE - systémová embolie; TIA - transitorní ischemická ataka; VKA - antagonisté vitaminu $\mathrm{K}$.

u oddálené kardioverze byl významně kratší u pacientů s rivaroxabanem.

Prof. MUDr. Josef Kautzner, CSc. (Klinika kardiologie, IKEM, Praha) ukázal, že echokardiografie je základní diagnostickou metodou použitelnou u pacientů s FS. Dovoluje posoudit velikost levé síně, která je silným prediktorem vzniku FS a výskytu kardiovaskulárních příhod u FS, dále morfologii ouška a jeho rychlosti a umožňuje vyloučit trombózu v oušku. Používá se stále častěji k periprocedurální monitoraci výkonů, jako jsou katetrizační ablace nebo uzávěr ouška levé síně.

\section{Přínos rivaroxabanu $v$ léčbě tromboembolické nemoci potvrzují praktické zkušenosti}

Třetí symposium bylo věnováno léčbě tromboembolické nemoci. Jak ukázal doc. MUDr. Jaromír Chlumský, Ph.D. (Interní klinika, 2. LF UK a FN v Motole, Praha), v léčbě TEN vykázal rivaroxaban minimálně stejnou nebo lepší účinnost než warfarin, nižší riziko krvácení (obr. 3) a větší pohodlí pro pacienta. Vyplývá to ze sdružených údajů ze studií EINSTEIN DVT a EINSTEIN PE zahrnující 8282 pacientů. Rivaroxaban patří mezi prípravky doporučené American College of Clinical Pharmacy (ACCP) pro počáteční léčbu TEN. Př́nos rivaroxabanu v léčbě TEN byl prokázán i u rizikových pacientů: nad 75 let věku a $\mathrm{s} \mathrm{CrCl}<50 \mathrm{ml} / \mathrm{min}$. Rivaroxaban se u TEN podává v dávce dvakrát denně $15 \mathrm{mg}$ prvních 21 dní, poté $20 \mathrm{mg}$ jednou denně. Snížení rizika recidiv TEN v prvních šesti týdnech po první příhodě dokládá, že rivaroxaban má dávkovací režim ochraňující pacienta před recidivou žilní trombózy v nejrizikovějším období.

Jak potvrdil MUDr. Jiří Veselý (Interní oddělení, Nemocnice Náchod), léčba žilní trombózy a plicní embolie nemusí začínat intravenózně ani parenterálně podávaným lékem. Použití léku nevyžadujícího monitoraci může být stejně účinné a bezpečnější než klasická léčba nízkomolekulárním heparinem (LMWH) a warfarinem. Výsledky klinických studií doložil vlastními zkušenostmi s rivaroxabanem z Interního oddělení Nemocnice Náchod,

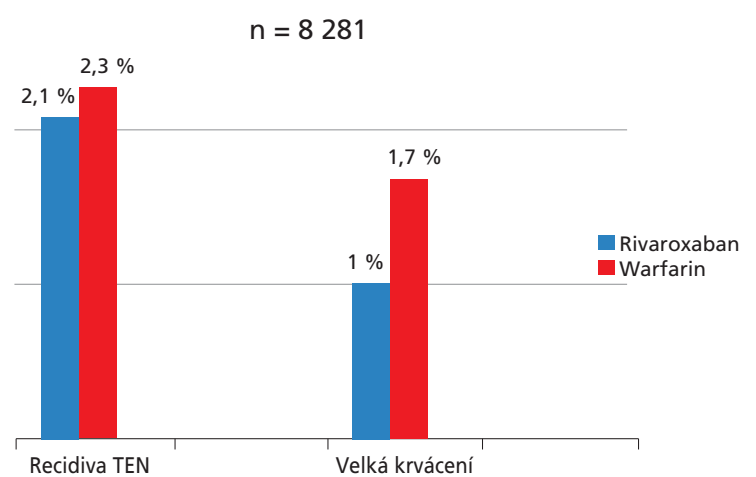

Obr. 3 - Rivaroxaban snižuje riziko recidivy TEN s nižším rizikem krvácení než warfarin: sdružené údaje ze studií EINSTEIN DVT a EINSTEIN PE.

TEN - tromboembolická nemoc.

a to včetně fragilních pacientů: starších 75 let, $\mathrm{s} \mathrm{CrCl}<50$ $\mathrm{ml} / \mathrm{min}$ či hmotností do $50 \mathrm{~kg}$. Jak uzavřel, rivaroxaban představuje účinnou a bezpečnou léčbu TEN. Tato léčba je v praxi dobře uplatnitelná i u pacientů, kteří jsou pro TEN hospitalizováni.

Doc. MUDr. Petr Dulíček, Ph.D. (IV. interní hematologická klinika, LF UK a FN Hradec Králové) připomněl, že současná terapie TEN je účinná, ale složitější a omezuje pacienta. Vyzdvihl tzv. single drug princip, tj. léčbu jedním perorálním lékem, bez nutnosti injekcí, převodu na jiný přípravek a monitorace, který může léčbu značně zjednodušit.

Doc. MUDr. Pavel Jansa, Ph.D. (Komplexní kardiovaskulární centru VFN Praha) se věnoval tématu chronické tromboembolické plicní hypertenze (CTEPH). Upozornil, že pro nezanedbatelnou část těchto pacientů není chirurgická léčba definitivním řešením. První registrovanou specifickou farmakoterapií pro pacienty s inoperabilní/reziduální $\mathrm{CTEPH}$ je riociguat. Zlepšuje hemodynamiku, hodnotu natriuretického peptidu typu B (BNP), třídu NYHA, funkční zdatnost, kvalitu života a prognózu pacientů.

Připravila MUDr. Zuzana Zafarová 